\title{
Indicators of microbial beach water quality: preliminary findings from Teluk Kemang beach, Port Dickson (Malaysia)
}

\begin{abstract}
This study aims to determine the concentrations of total coliforms and Escherichia coli (E. coli) in beach water, Teluk Kemang beach. This study was also aimed to determine relationship between total coliforms, E. coli and physicochemical parameters. As perceived health symptoms among beach visitors are rarely incorporated in beach water studies, this element was also assessed in this study. A total of eight water sampling points were selected randomly along Teluk Kemang beach. Total coliforms concentrations were found between 20 and $1940 \mathrm{cfu} / 100 \mathrm{ml}$. E. coli concentrations were between 0 and $90 \mathrm{cfu} / 100 \mathrm{ml}$. Significant correlations were found between total coliforms and E. coli with $\mathrm{pH}$, temperature and oxidation reduction potential. Skin and eyes symptoms were the highest reported though in small numbers. Microbiological water quality in Teluk Kemang public beach was generally safe for recreational activities except sampling location near with sewage outfall.
\end{abstract}

Keyword: Beach water; E. coli; Perceived health symptoms; Total coliforms 